\section{EFFECT OF PATENT DUCTUS ARTERIOSUS (PDA) \& RESPIRATORY SUPPORT ON OXYGEN SATURATION IN PRETERM BABIES?}

doi:10.1136/archdischild-2012-302724.1788

${ }^{1} \mathrm{~S}$ Gupta, ${ }^{2} \mathrm{P}$ Suresh, ${ }^{1} \mathrm{P}$ Mallaya, ${ }^{1} \mathrm{C}$ Harikumar. ${ }^{1}$ Neonatology \& Paediatrics, University Hospital of North Tees, Stockton-on-Tees; 'Medical School, Newcastle University, Newcastle upon Tyne, UK

Background Oxygen saturations in premature babies are targeted between $91-94 \%$. However presence of a PDA and respiratory support have been attributed to fluctuations in oxygen saturations. Aim To study the effect of PDA and respiratory support on frequency and duration of desaturations in premature babies.

Methods Babies <32 weeks' gestation admitted to the tertiary level neonatal unit were included in this prospective study. Saturations were recorded using the Masimo ${ }^{\circledR}$ pulse oximeters that recorded data every 2 seconds. The data was downloaded and analysed using SPSS ${ }^{\circledR}$ version19. Babies were divided into 4 groups based on the presence of a PDA $(>1.5 \mathrm{~mm})$ and respiratory support (ventilation/CPAP) (Table 1).

Results Thirty six ( $\sim 6$ hour each) recordings were made and $\sim 500,000$ records captured.

In babies with a PDA the duration of desaturations was significantly longer.

Babies on respiratory support had significantly lower saturations and also significantly longer periods of saturation $<90 \%$ or $<86 \%$.

Abstract 1788 Table 1: Pulse oximetry data in four study groups

\begin{tabular}{|c|c|c|c|c|c|c|c|}
\hline Soudy group & $\begin{array}{l}\text { No. of } \\
\text { measure } \\
\text { menss }\end{array}$ & $\begin{array}{l}\text { Sahueati } \\
\text { on: } \\
\text { Mean(S } \\
\text { D) }\end{array}$ & $\begin{array}{l}\text { Dipshir, } \\
\text { Mranis } \\
\text { D) }\end{array}$ & $\begin{array}{l}\text { Average } \\
\text { duratios of } \\
\text { dips (sec) } \\
\text { Mean(SD) }\end{array}$ & $\begin{array}{l}\text { Satsc90 (N) } \\
\text { of ncconding } \\
\text { duratice) } \\
\text { Mcan(SD) }\end{array}$ & $\begin{array}{l}\text { Salurabionse } \\
86 \% 6(\% \text { of } \\
\text { recondieg } \\
\text { duratice) }\end{array}$ & $\begin{array}{l}\text { Pulse rate; } \\
\text { Mean(SD) }\end{array}$ \\
\hline $\begin{array}{l}\text { (1) PDA* } \\
\text { Resp supeen + }\end{array}$ & 117,000 & $\begin{array}{l}92.00 \\
(2.16)\end{array}$ & $\begin{array}{l}14.04 \\
(12.67)\end{array}$ & $\begin{array}{l}30.50 \\
(12.16)\end{array}$ & $14.7(12.4)$ & $6 \times 47.7)$ & $153(14)$ \\
\hline $\begin{array}{l}\text { (2) PDA- } \\
\text { No resp, supeont }\end{array}$ & 97,000 & $\begin{array}{l}95.49 \\
(1.79)\end{array}$ & $\begin{array}{l}71.77 \\
(7.90)\end{array}$ & $\begin{array}{l}24.50 \\
(10.95)\end{array}$ & $4.8(8.9)$ & $1 . x(3,4)$ & 14r(11) \\
\hline $\begin{array}{l}\text { (3) No PDA } \\
\text { Resp supeort . }\end{array}$ & 64,000 & $\begin{array}{l}9364 \\
0.08)\end{array}$ & $\begin{array}{l}22.40 \\
(26303\end{array}$ & $\begin{array}{l}14.17 \\
0.38)\end{array}$ & $14.917 .3)$ & $5.7(7 . \times)$ & $147(16)$ \\
\hline $\begin{array}{l}\text { (4) No PDA } \\
\text { Ne reop support }\end{array}$ & 169,200 & $\begin{array}{l}94.67 \\
(2.22)\end{array}$ & $\begin{array}{l}36.51(1 \\
9.53)\end{array}$ & $\begin{array}{l}12.07 \\
16.08)\end{array}$ & $8.5(9.1)$ & $2 \times(4.0)$ & $154(5)$ \\
\hline
\end{tabular}

Conclusions In babies with PDA the desaturation episodes are significantly longer but the saturations are consistent.

Babies on respiratory support have lower saturations and frequent fluctuations in saturations as compared to babies not on any support.

\section{BRONCHOALVEOLAR INTERLEUKIN-1 BETA: A MARKER OF BACTERIAL BURDEN IN LONG TERM MECHANICAL VENTILATION NEWBORN WITH VENTILATOR-ASSOCIATED PNEUMONIA}

doi:10.1136/archdischild-2012-302724.1789

D Dmytriiev, 0 Katilov, 0 Mazulov, K Dmytriieva. Anesthesiology and Intensive Care, Vinnitsa National Medical University, Vinnitsa, Ukraine

Objective To assess the relationship between concentrations of bronchoalveolar cytokines and bacterial burden (quantitative bacterial count) in long term mechanical ventilation newborn with a presumptive diagnosis of ventilator-associated pneumonia.

Interventions According to the time course of ventilator-associated pneumonia at the time of study with bronchoalveolar lavage, 44 newborn were divided into two subgroups: referral $(n=18)$, and treated $(n=26)$ ventilator-associated pneumonia. Bronchoalveolar lavage was performed in the most abnormal area on chest radiograph by fiberoptic bronchoscope. Bronchoalveolar lavage fluid was processed for quantitative bacterial culture. The concentrations of bronchoalveolar lavage cytokines (tumor necrosis factor-alpha, interleukin-1 beta, interleukin-6) also were measured.

Measurements and Main Results 26 patients had a positive bacterial culture (bronchoalveolar lavage $>$ or $=10$ colony-forming units $/ \mathrm{mL}$ ), and made up $79 \%$ of pathogens recovered at high concentrations. The concentrations of bronchoalveolar lavage interleukin-1 beta were $200.4+/-22.4$ and $44.8+/-14.2 \mathrm{pg} / \mathrm{mL}$ (mean $+/-\mathrm{se}$ ) in the newborn with positive and negative bacterial culture, respectively $(p<0.001)$. Bronchoalveolar lavage interleukin- 1 beta was significantly higher in the newborn with a high bacterial burden $(p<0.001)$, with mixed bacterial infection $(p<0.001)$, and with ventilator-associated pneumonia $(p<0.001)$, compared with values in patients without these features.

Conclusions Since the concentration of bronchoalveolar lavage interleukin-1 beta was correlated with bacterial burden in the alveoli, it may be a marker for progressive and ongoing inflammation in long term mechanical ventilation newborn.

\section{OXIDATIVE STRESS AND CLINICAL OUTCOME OF PRETERM INFANTS RESUSCITATED WITH DIFFERENT CONCENTRATIONS OF OXYGEN}

doi:10.1136/archdischild-2012-302724.1790

'S Aversa, 'L Marseglia, 'A Arco, 'M Manfrida, ${ }^{2} \mathrm{C}$ Salpietro, 'I Barberi, ${ }^{3} \mathrm{RJ}$ Reiter, 'E Gitto. 'Neonatal Intensive Care Unit, Department of Paediatrics; ' $G e n e t i c s$ and Paediatric Immunology, Department of Paediatrics, University of Messina, Messina, Italy; ${ }^{3}$ Department of Cellular and Structural Biology, The University of Texas Health Science Center, San Antonio, TX, USA

Background and Aims Preterm infants are more sensitive to oxidative stress than older humans. Hyperoxic exposure, although essential for survival of neonates, induces excessive production of reactive oxygen metabolites which could be responsible of morbidities in these babies. Aims of this study were to evaluate the incidence of mortality and bronchodysplasia in preterm infants resuscitated at birth with different concentrations of oxygen. Secondary outcome was to evaluate the serum level of oxdative stress markers in the same population of infants.

Methods A randomized clinical trial has been performed in NICU of University of Messina, Italy.

Results 60 preterm infants (gestational age $<32$ weeks) were recruited and randomly divided into three groups (40\%, 60\% and $100 \%$ of fractional inspired oxygen). We didn't find difference in mortality $(p 0,877)$, but bronchodysplasia was represented only in the group of $100 \%$ oxygen $(p<0.01)$. These newborns had also a longer time of ventilation $(p 0,001)$ and hospitalization $(p 0,007)$ and a higher incidence of pneumothorax $(p<0.01)$. Serum levels of Interleukin-1 $\beta$ and nitrosylated protein were higher in preterm infants resuscitated with $100 \%$ oxygen in comparison with the other two groups of infants, which instead presented a significant reduction of interleukin-10 levels.

Conclusions In our study, the exposure of preterm infants to higher oxygen concentrations at birth is correlated with poor respiratory outcome without influencing neonatal mortality. Imbalances between pro- and anti-inflammatory cytokines may therefore be early indicators of developing chronic lung disease.

\section{COMPARISON BETWEEN HELIOX AND STANDARD OXYGEN- AIR MIXTURE FOR AEROSOLIZED ALBUTEROL SULFATE DELIVERY UNDER NEONATAL MECHANICAL VENTILATION CONDITIONS-IN VITRO STUDY}

doi:10.1136/archdischild-2012-302724.1791 